\title{
Calcium signaling involved in bovine herpesvirus 1 replication in MDBK cells
}

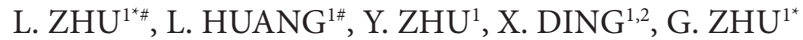

\begin{abstract}
${ }^{1}$ College of Veterinary Medicine, Yangzhou University, 48 Wenhui East Road, Yangzhou, Jiangsu, 225009 and Jiangsu Co-innovation Center for Prevention and Control of Important Animal Infectious Diseases and Zoonoses, 48 Wenhui East Road, Yangzhou 225009, P. R. China; ${ }^{2}$ Test Center, Yangzhou University, 48 Wenhui East Road, Yangzhou, Jiangsu, 225009, P. R. China
\end{abstract}

Received October 24, 2016; revised February 10, 2017; accepted October 13, 2017

\begin{abstract}
Summary. - Calcium is one of the most prominent second messengers in eukaryotic cells. The involvement of calcium signaling in bovine herpesvirus 1 (BoHV-1) replication was not yet reported. In this study, we revealed that the L-type $\mathrm{Ca}^{2+}$ calcium channel blocker, Verapamil and store-operated calcium channel blocker, 2-aminoethyl diphenylborinate (2-APB) inhibited BoHV-1 replication in MDBK cells at the post-entry stages, and the $\mathrm{Na}^{+} / \mathrm{Ca}^{2+}$ exchanger inhibitor, $\mathrm{N}$-arachidonoyl glycine exchanger (NAGly) interfered with the viral entry process. NAGly also effected the phosphorylation of PLC $\gamma-1$ at Ser1248, which corroborated our previous findings, that PLC $\gamma-1$ is important for BoHV-1 entry. Collectively, these results suggest that diverse calcium channels are employed by BoHV-1 for efficient replication.
\end{abstract}

Keywords: BoHV-1; calcium; calcium channel blocker

Bovine herpesvirus 1 (BoHV-1), an enveloped virus belonging to the Alphaherpesvirus subfamily, infects cattle of all ages and breeds worldwide and causes great economical losses to cattle farms, due to the virus infection induced respiratory disease, abortions, and severe neonatal diseases (Muylkens et al., 2007; Tikoo et al., 1995). BoHV-1 together with the other pathogens, such as bovine viral diarrhea viruses, bovine respiratory syncytial virus, parainfluenza virus type 3 and bovine coronaviruses, as well as the bacteria including Mannheimia haemolytica, Pasteurella multocida, Histophilus somni and Mycoplasma spp are the causative agents of life-threatening pneumonia known as bovine respiratory disease complex (BRDC) (Fulton et al., 2016; Jones, 2009; Jones and Chowdhury, 2007).

$\mathrm{Ca}^{2+}$ is one of the most important signaling molecules involved in vast majority of cellular processes via modulating the activity of a repertoire of signaling components, such as

*Corresponding authors. E-mail: lzhu3596@163.com (Liqian Zhu), yzgqzhu@yzu.edu.cn (Guoqiang Zhu); phone: +86514-87990797. "Contributed equally to this work.

Abbreviations: BoHV-1 = bovine herpes virus 1; 2-APB = 2-aminoethyl diphenylborinate; NAGly $=\mathrm{N}$-arachidonoyl glycine; $\mathrm{PLC}=$ phospholipase $\mathrm{C} ; \mathrm{VOC}=$ voltage-operated channel; SOC $=$ store-operated channel; $\mathrm{NCX}=\mathrm{Na}^{+} / \mathrm{Ca}^{2+}$ the ion channels, $\mathrm{Ca}^{2+}$ buffers, $\mathrm{Ca}^{2+}$ effectors, $\mathrm{Ca}^{2+}$-sensitive enzymes and transcriptional factors (Berridge et al., 2003; Zhou et al., 2009). It is well known that the virus depends on the cellular machinery for efficient entry of the host cells and subsequent replication and survival. It is not surprising that the viruses could utilize $\mathrm{Ca}^{2+}$ signals to create a favorable cellular environment benefiting for their infection, e.g., the $\mathrm{Ca}^{2+}$ is strictly required for rubella virus liposome association, membrane fusion, and virus infection (Dube et al., 2014); the endosomal calcium channels called two pore channels (TPCs) are required for Ebola virus entry into host cells (Sakurai et al., 2015); stromal interaction molecule 1 (STIM1)- and Orai-mediated $\mathrm{Ca}^{2+}$ entry is critical for Ebola virus, Marburg, Lassa and Junin virus infections (Han et al., 2015); and calcium signaling is a key regulator of influenza virus internalization (Fujioka et al., 2013). The involvement of calcium signaling in herpes simplex virus (HSV) infection has also been reported (Cheshenko et al., 2003). BoHV-1 and HSV are genetically closed, but little is known about the involvement of $\mathrm{Ca}^{2+}$ signaling in BoHV-1 infection.

Phospholipases C (PLC) with totally of 6 families $(\beta, \gamma, \delta$, $\varepsilon, \eta$ and $\zeta$ ) are subdivided into 13 isoforms, which regulate numerous pathways, such as protein kinase $\mathrm{C}$ (PKC) and calcium spike (Vines, 2012). We have previously reported 
(a)

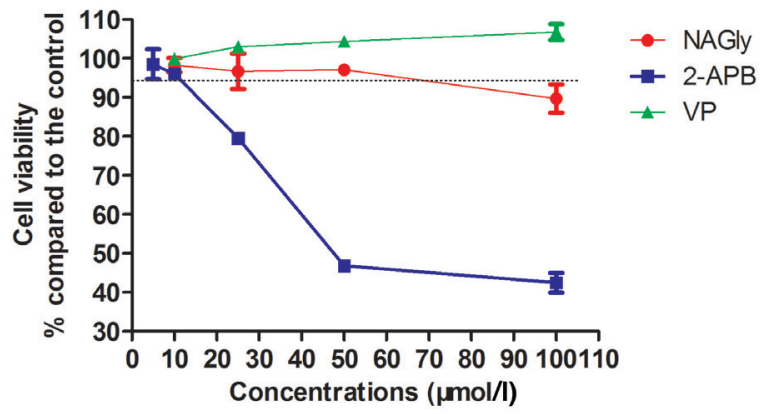

(b)

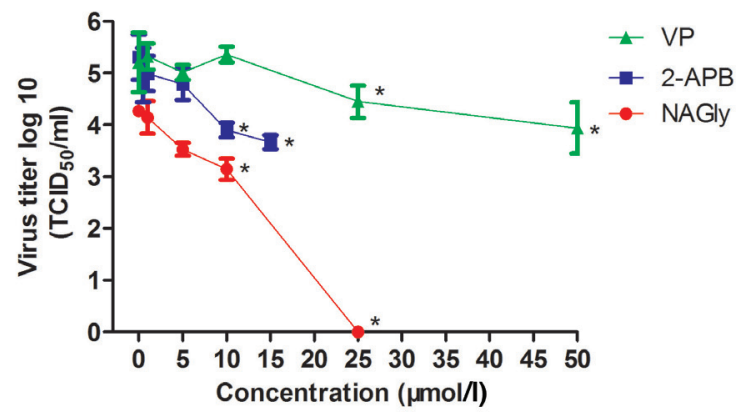

(c)

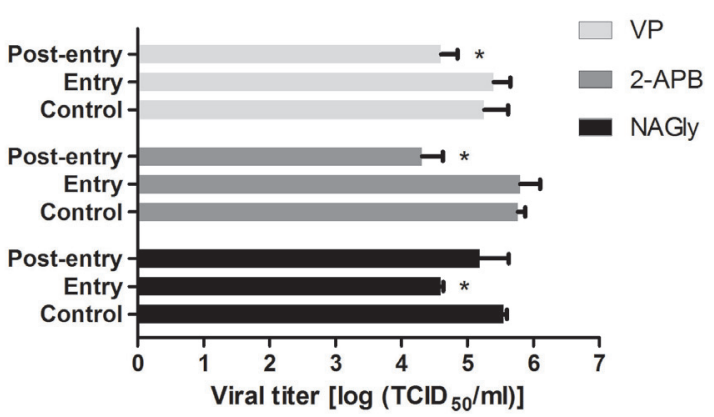

Fig. 1

The effects of Verapamil, 2-APB, and NAGly on BoHV-1 replication in MDBK cells

(a) The cytotoxicity assay for Verapamil, 2-APB and NAGly at indicated concentrations in MDBK cells. (b) Antiviral effect of Verapamil, 2-APB and NAGly on BoHV-1 infection. (c) The identification of virus entry stage(s) affected by these inhibitors. These studies were repeated 3 times and asterisks denote significant differences between the DMSO control and cultures treated with indicated chemical $\left({ }^{*}: P<0.05\right)$ as determined by the Student' $t$ test.

that PLC $\gamma$-1 inhibitor U73122 and edelfosine possess strong antiviral activity against BoHV-1 infection, and are likely to interfere with viral early entry stages (Zhu et al., 2017). This result is reminiscent of the speculation that some calcium channels may be involved in BoHV-1 infection.

Various $\mathrm{Ca}^{2+}$ channels, such as voltage-operated channel (VOC), receptor-operated channel (ROC) or store-operated channel (SOC) are responsible for feeding extracellular $\mathrm{Ca}^{2+}$ to the cytosol. These channels are extensively studied due to the availability of specific channel blockers, e.g., Verapamil for VOC and 2-aminoethyl diphenylborinate (2-PAB) for SOC. $\mathrm{Na}^{+} / \mathrm{Ca}^{2+}$ exchanger (NCX) is considered as one of the most important cellular mechanisms for extruding $\mathrm{Ca}^{2+}$ to the extracellular space. In this study, VOC blocker Verapamil (\#V4629; Sigma-Aldrich), SOC blocker 2-APB (\#D9754; Sigma-Aldrich), and NCX inhibitor N-arachidonoyl glycine (NAGly) (\#CAS 179113-91-8; Santa Cruz Biotechnology) were employed to investigate the role of the calcium channels in BoHV-1 infection.

To identify proper concentrations for this study, the cytotoxicity of each chemical was assessed with WST-1 cell proliferation and cytotoxicity assay kit (Beyotime Biotechnology, China) following the manufacture's specification. As a result, the treatment of MDBK cells with Verapamil at a concentration of $100 \mu \mathrm{mol} / \mathrm{l}$, with 2 -APB at a concentration of $15 \mu \mathrm{mol} / \mathrm{l}$, and with NAGly at a concentration of $50 \mu \mathrm{mol} / \mathrm{l}$ showed minor or no cytotoxicity to the cells, with reduced cell survival to a level less than 5\% compared to the control (Fig. 1a). To test the effect of these chemicals on BoHV-1 infection, MDBK cells were treated with Verapamil (at a concentration of 50, 25, 10, 5 and $1 \mu \mathrm{mol} / \mathrm{l}$ ), 2-APB (at a concentration of $15,10,5,1$ and $0.5 \mu \mathrm{mol} / \mathrm{l}$ ) and NAGly (at a concentration of $25,10,5$ and $1 \mu \mathrm{mol} / \mathrm{l}$ ), respectively, during virus infection with a pretreatment for $1 \mathrm{~h}$ prior to viral infection. The infected cells treated with DMSO were used as a control. At $24 \mathrm{~h}$ post-infection the viral titer was determined and expressed as $\mathrm{TCID}_{50} / \mathrm{ml}$. Compared to DMSO control, Verapamil reduced the virus titer by $\sim 1$ log at concentrations of 50 and $25 \mu \mathrm{mol} / 1,2-\mathrm{APB}$ reduced the virus yield by $\sim 1.5 \log$ at concentrations of 50 and $25 \mu \mathrm{mol} / \mathrm{l}$, and NAGly at a concentration of $25 \mu \mathrm{mol}$ completely blocked the virus replication (Fig. 2b). These results indicate that VOC, SOC, and NCX exchanger mediated calcium signaling are important for BoHV-1 infection.

To test whether these inhibitors affected the viral entry stage of infection, confluent MDBK cells in a 24 -well plate were incubated with BoHV-1(MOI $=1)$ for $1 \mathrm{~h}$ at $4^{\circ} \mathrm{C}$. After extensive washing with ice-cold PBS, fresh medium with or without compounds were added, and the cells were cultivated in $37^{\circ} \mathrm{C}$ for $1 \mathrm{~h}$. Fresh medium without inhibitor was replaced and continuously incubated for $24 \mathrm{~h}$ at $37^{\circ} \mathrm{C}$. The virus yield was determined and expressed as $\mathrm{TCID}_{50} / \mathrm{ml}$. Addition of NAGly $(10 \mu \mathrm{mol} / \mathrm{l})$ during virus entry significantly reduced virus titer $(\sim 1 \log )$ when compared to control. While, no effect on the virus replication was observed when either Verapamil $(50 \mu \mathrm{mol} / \mathrm{l})$ or 2 -APB $(10 \mu \mathrm{mol} / \mathrm{l})$ was added (Fig. 1c). To test whether these inhibitors affect the postentry stage of BoHV-1 infection, confluent MDBK cells in 24-well plates were infected with BoHV-1 (MOI = 1) for $1 \mathrm{~h}$ at $37^{\circ} \mathrm{C}$. After washing with PBS, fresh medium with 
or without inhibitors was replaced for further incubation. At $24 \mathrm{~h}$ post-infection, the virus yield was determined as $\mathrm{TCID}_{50} / \mathrm{ml}$. As a result, the treatment of cells with both Verapamil $(50 \mu \mathrm{mol} / \mathrm{l})$ and 2 -APB $(10 \mu \mathrm{mol} / \mathrm{l})$, but not NAGly $(10 \mu \mathrm{mol} / \mathrm{l})$ significantly interfered with the virus production. These results indicate that the VOC blocker Verapamil and SOC blocker 2-APB mainly affected the virus post-entry stages, while the NCX inhibitor NAGly mainly interfered with viral entry process.

We have recently identified that BoHV-1 infection stimulated PLC $\gamma-1$ signaling to facilitate the viral entry (Zhu et al., 2017). However, the mechanism underlying virus infection-stimulated PLC $\gamma-1$ signaling is poorly understood. Here, serum- starved MDBK cells were treated with NAGly at indicated concentrations for $1 \mathrm{~h}$, then infected with BoHV-1 at MOI of 10 for $0.5 \mathrm{~h}$, along with the treatment of NAGly. The cell lysates were prepared for western blot to detect phospho-PLC $\gamma$-1 (Ser1248) (Cell Signaling Technology), PLC $\gamma$-1 (Cell Signaling Technology) and GAPDH (Cell Signaling Technology). As a result, the activation of PLC $\gamma-1$ in response to BoHV-1 infection was reduced in a dose-dependent manner (Fig. 2). These results suggest that the NCX-mediated calcium signaling may be involved in the activation of PLC $\gamma-1$ by BoHV-1 infection. It has been reported that the activation of $\mathrm{PLC} \gamma-1$ by calcium is required for calcium-induced human keratinocyte differentiation (Xie et al., 2005), which corroborated our results that calcium signaling is involved in PLC $\gamma$-1activation in response to BoHV-1 infection.

$2-\mathrm{APB}$ is a reliable blocker of store-operated $\mathrm{Ca}^{2+}$ entry (Bootman et al., 2002; Peppiatt et al., 2003). The inhibition of viral entry by 2 -APB has been documented by several viruses, e.g., 2-APB inhibited HSV-1/2 penetration (Cheshenko et al., 2003), and pretreatment of cells with 2-APB led to a significant reduction in coxsackie virus $B$ infection (Bozym et al., 2010). No inhibitory effect on West Nile virus infection was observed at the viral entry stages (Scherbik and Brinton, 2010). Here, we found that 2-APB affected the BoHV-1 replication mainly at the post-entry stage, but not at the entry stages. These data suggest that the store-operated $\mathrm{Ca}^{2+}$ entry may have diverse effect on virus replication in virus type-specific manner.

The voltage-operated channel antagonist Verapamil is a drug approved by the U.S. Food and Drug Administration (FDA) to treat cardiovascular diseases. This drug has also diverse effects on various virus infections. Verapamil enhanced some virus infections, e.g., like HIV-1 expression in acute infection of lymphoid CEM cells (Harbison et al., 1991), and promotes oncolytic adenovirus release from the infected A549 cells (Gros et al., 2010). Whilst, the antiviral effect of Verapamil targeting various process of viral replication has also been documented, e. g., it inhibits filovirus entry to host cells (Gehring et al., 2014), inhibits budding

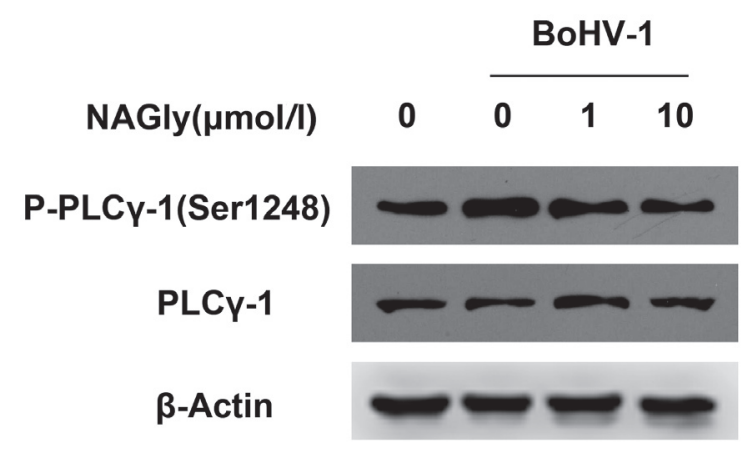

Fig. 2

NAGly interferes with PLC $\gamma$-1 phosphorylation (at Ser1248) in BoHV-1-infected MDBK cells

Western blot of phospho-PLC $\gamma$-1 (Ser1248), PLC $\gamma$-1 and GAPDH. MDBK cells subjected to serum starvation for $12 \mathrm{~h}$ were treated with NAGly at indicated concentrations for $1 \mathrm{~h}$, followed by infection with BoHV-1 at MOI of 10 for $0.5 \mathrm{~h}$, along with the treatment of NAGly. These results are representative of three independent experiments.

of Sindbis and vesicular stomatitis viruses from infected chicken embryo fibroblasts (Schlesinger and Cahill, 1989), and blocks human rhinovirus 2 infection and release (Gazina et al., 2005; Schlesinger and Cahill, 1989). Here, we revealed that Verapamil interferes with BoHV-1 infection at the postentry stage(s).

There is a complicated interaction between phospholipase $\mathrm{C}$ and calcium signaling. Upon activation PLC activates protein kinase $\mathrm{C}$ (PKC) and $\mathrm{Ca}^{2+}$ release from the endoplasmic reticulum to the cytoplasm, and in turn activates downstream effectors to mediate various cellular changes and activities (Bagley et al., 2004; Vines, 2012). The NCX is responsible for extrusion of $\mathrm{Ca}^{2+}$ to the extracellular space and import of sodium ions. There is evidence of the activation of PLC by a $\mathrm{Na}^{+}$-dependent mechanism in MIN6 cells (Li et al., 2016). Here we showed that NCX also affects PLC $\gamma-1$ signaling stimulated by BoHV-1 infection. Maybe the activation of PLC $\gamma-1$ by the virus infection is orchestrated by NCX mediated calcium signaling, which needs further investigation.

In conclusion, we provide the first evidence that BoHV-1 infection in MDBK cells could be inhibited by diverse calcium channel blockers, suggesting that host $\mathrm{Ca}^{2+}$ signaling is involved in the virus infection. Moreover, we have showed that NCX-mediated calcium signaling mediated BoHV-1 entry is regulated with a PLC $\gamma$-1-dependent mechanism.

Acknowledgements. We thank Dr. Leonard J Bello, University of Pennsylvania, USA for providing the BoHV-1 Colorado 1 stain and MDBK cells. This research was supported by Chinese National Science Foundation Grant (No.31472172), and partially supported 
by Grant No. 2016YFD0500900 and 2016YFD0500704 from the National Key Research and Development Program of China, the Priority Academic Program Development of Jiangsu Higher Education Institutions (PAPD), the grant No. 14KJA230001 from the Jiangsu High Education Basic Research, the grant No. BE2014358 from the Science and Technology Department of Jiangsu province.

\section{References}

Bagley KC, Abdelwahab SF, Tuskan RG, Lewis GK (2004): Calcium signaling through phospholipase $\mathrm{C}$ activates dendritic cells to mature and is necessary for the activation and maturation of dendritic cells induced by diverse agonists. Clin. Diagn. Lab. Immunol. 11, 77-82. https://doi. org/10.1128/CDLI.11.1.77-82.2004

Berridge MJ, Bootman MD, Roderick HL (2003): Calcium signalling: dynamics, homeostasis and remodelling. Nat. Rev. Mol. Cell. Biol. 4, 517-529. https://doi.org/10.1038/ $\underline{\text { nrm } 1155}$

Bootman MD, Collins TJ, Mackenzie L, Roderick HL, Berridge MJ, Peppiatt CM (2002): 2-aminoethoxydiphenyl borate (2-APB) is a reliable blocker of store-operated $\mathrm{Ca} 2+$ entry but an inconsistent inhibitor of InsP3-induced Ca2+ release. FASEB J. 16, 1145-1150. https://doi.org/10.1096/ f. $02-0037 \mathrm{rev}$

Bozym RA, Morosky SA, Kim KS, Cherry S, Coyne CB (2010): Release of intracellular calcium stores facilitates coxsackievirus entry into polarized endothelial cells. PLoS Pathog. 6, e1001135. https://doi.org/10.1371/journal. ppat.1001135

Cheshenko N, Del Rosario B, Woda C, Marcellino D, Satlin LM, Herold BC (2003): Herpes simplex virus triggers activation of calcium-signaling pathways. J. Cell. Biol. 163, 283-293. https://doi.org/10.1083/jcb.200301084

Dube M, Rey FA, Kielian M (2014): Rubella virus: first calciumrequiring viral fusion protein. PLoS Pathog. 10, e1004530. https://doi.org/10.1371/journal.ppat.1004530

Fujioka Y, Tsuda M, Nanbo A, Hattori T, Sasaki J, Sasaki T, Miyazaki T, Ohba Y (2013): A Ca (2+)-dependent signalling circuit regulates influenza $\mathrm{A}$ virus internalization and infection. Nat. Commun. 4, 2763. https://doi.org/10.1038/ ncomms 3763

Fulton RW, d'Offay JM, Landis C, Miles DG, Smith RA, Saliki JT, Ridpath JF, Confer AW, Neill JD, Eberle R, Clement TJ, Chase CC, Burge LJ, Payton ME (2016): Detection and characterization of viruses as field and vaccine strains in feedlot cattle with bovine respiratory disease. Vaccine 34, 3478-3492. https://doi.org/10.1016/j. vaccine.2016.04.020

Gazina EV, Harrison DN, Jefferies M, Tan H, Williams D, Anderson DA, Petrou S (2005): Ion transport blockers inhibit human rhinovirus 2 release. Antiviral Res. 67, 98-106. https:// doi.org/10.1016/j.antiviral.2005.05.003

Gehring G, Rohrmann K, Atenchong N, Mittler E, Becker S, Dahlmann F, Pohlmann S, Vondran FW, David S, Manns MP, Ciesek S, von Hahn T (2014): The clinically ap- proved drugs amiodarone, dronedarone and verapamil inhibit filovirus cell entry. J. Antimicrob. Chemother. 69, 2123-2131. https://doi.org/10.1093/jac/dku091

Gros A, Puig C, Guedan S, Rojas JJ, Alemany R, Cascallo M (2010): Verapamil enhances the antitumoral efficacy of oncolytic adenoviruses. Mol. Ther. 18, 903-911. https://doi. org/10.1038/mt.2010.22

Han Z, Madara JJ, Herbert A, Prugar LI, Ruthel G, Lu J, Liu Y, Liu W, Liu X, Wrobel JE, Reitz AB, Dye JM, Harty RN, Freedman BD (2015): Calcium regulation of hemorrhagic fever virus budding: mechanistic implications for host-oriented therapeutic intervention. PLoS Pathog. 11, e1005220. https://doi.org/10.1371/journal.ppat.1005220

Harbison MA, Kim SY, Gillis JM, Hammer SM (1991): Effect of the calcium channel blocker verapamil on human immunodeficiency virus type 1 replication in lymphoid cells. J. Infect. Dis. 164, 53-60. https://doi.org/10.1093/ infdis/164.1.53

Jones C (2009): Regulation of innate immune responses by bovine herpesvirus 1 and infected cell protein 0 (bICP0). Viruses 1, 255-275. https://doi.org/10.3390/v1020255

Jones C, Chowdhury S (2007): A review of the biology of bovine herpesvirus type 1 (BHV-1), its role as a cofactor in the bovine respiratory disease complex and development of improved vaccines. Anim. Health Res. Rev. 8, 187-205. https://doi.org/10.1017/S146625230700134X

Li L, Ohtsu Y, Nakagawa Y, Masuda K, Kojima, I (2016): Sucralose, an activator of the glucose-sensing receptor, increases ATP by calcium-dependent and -independent mechanisms. Endocr. J. 63, 715-725. https://doi.org/10.1507/ endocri.EJ16-0217

Muylkens B, Thiry J, Kirten P, Schynts F, Thiry E (2007): Bovine herpesvirus 1 infection and infectious bovine rhinotracheitis. Vet. Res. 38, 181-209. https://doi.org/10.1051/ vetres:2006059

Peppiatt CM, Collins TJ, Mackenzie L, Conway SJ, Holmes AB, Bootman MD, Berridge MJ, Seo JT, Roderick HL (2003): 2-Aminoethoxydiphenyl borate (2-APB) antagonises inositol 1,4,5-trisphosphate-induced calcium release, inhibits calcium pumps and has a use-dependent and slowly reversible action on store-operated calcium entry channels. Cell Calcium 34, 97-108. https://doi.org/10.1016/ S0143-4160(03)00026-5

Sakurai Y, Kolokoltsov AA, Chen CC, Tidwell MW, Bauta WE, Klugbauer N, Grimm C, Wahl-Schott C, Biel M, Davey RA (2015): Ebola virus. Two-pore channels control Ebola virus host cell entry and are drug targets for disease treatment. Science 347, 995-998. https://doi.org/10.1126/ science. 1258758

Scherbik SV, Brinton MA (2010): Virus-induced Ca2+ influx extends survival of west nile virus-infected cells. J. Virol. 84, 8721-8731. https://doi.org/10.1128/JVI.00144-10

Schlesinger MJ, Cahill D (1989): Verapamil and chlorpromazine inhibit the budding of Sindbis and vesicular stomatitis viruses from infected chicken embryo fibroblasts. Virology 168 187-190. https://doi.org/10.1016/0042-6822(89)90421-2

Tikoo SK, Campos M, Babiuk, LA (1995): Bovine herpesvirus 1 (BHV-1): biology, pathogenesis, and control. Adv. Virus 
Res. 45, 191-223. https://doi.org/10.1016/S0065-3527(08)60061-5

Vines CM (2012): Phospholipase C. Adv. Exp. Med. Biol. 740, 235-254. https://doi.org/10.1007/978-94-007-2888$\underline{210}$

Xie Z, Singleton PA, Bourguignon LY, Bikle DD (2005): Calciuminduced human keratinocyte differentiation requires src- and fyn-mediated phosphatidylinositol 3-kinasedependent activation of phospholipase C-gamma1. Mol.
Biol. Cell. 16, 3236-3246. https://doi.org/10.1091/mbc. E05-02-0109

Zhou Y, Frey TK, Yang JJ (2009): Viral calciomics: interplays between $\mathrm{Ca} 2+$ and virus. Cell Calcium 46, 1-17. https://doi. org/10.1016/j.ceca.2009.05.005

Zhu L, Yuan C, Ding X, Jones C, Zhu G (2017): The role of phospholipase $\mathrm{C}$ signaling in bovine herpesvirus 1 infection. Vet. Res. 48, 45. https://doi.org/10.1186/s13567-017$\underline{0450-5}$ 